\title{
Severity of Purple Blotch of Onion Caused by Alternaria porii in Northern Karnataka, India
}

\author{
S. Ravichandran ${ }^{1 *}$, B.C. Kamanna ${ }^{3}$, K. Jayalakshmi ${ }^{2}$, V.I. Benagi ${ }^{3}$ and K.B. Yadahalli ${ }^{3}$ \\ ${ }^{1}$ Regional Plant Quarantine Station, DPPQS, Chennai, Tamil Nadu, India \\ ${ }^{2}$ AINRP (Tobacco), ZAHRS, University of Agricultural and Horticultural Sciences, \\ Shivamogga- 577225, Karnataka, India \\ ${ }^{3}$ Department of Plant Pathology, University of Agricultural Sciences, \\ Dharwad- 580005, Karnataka, India \\ *Corresponding author
}

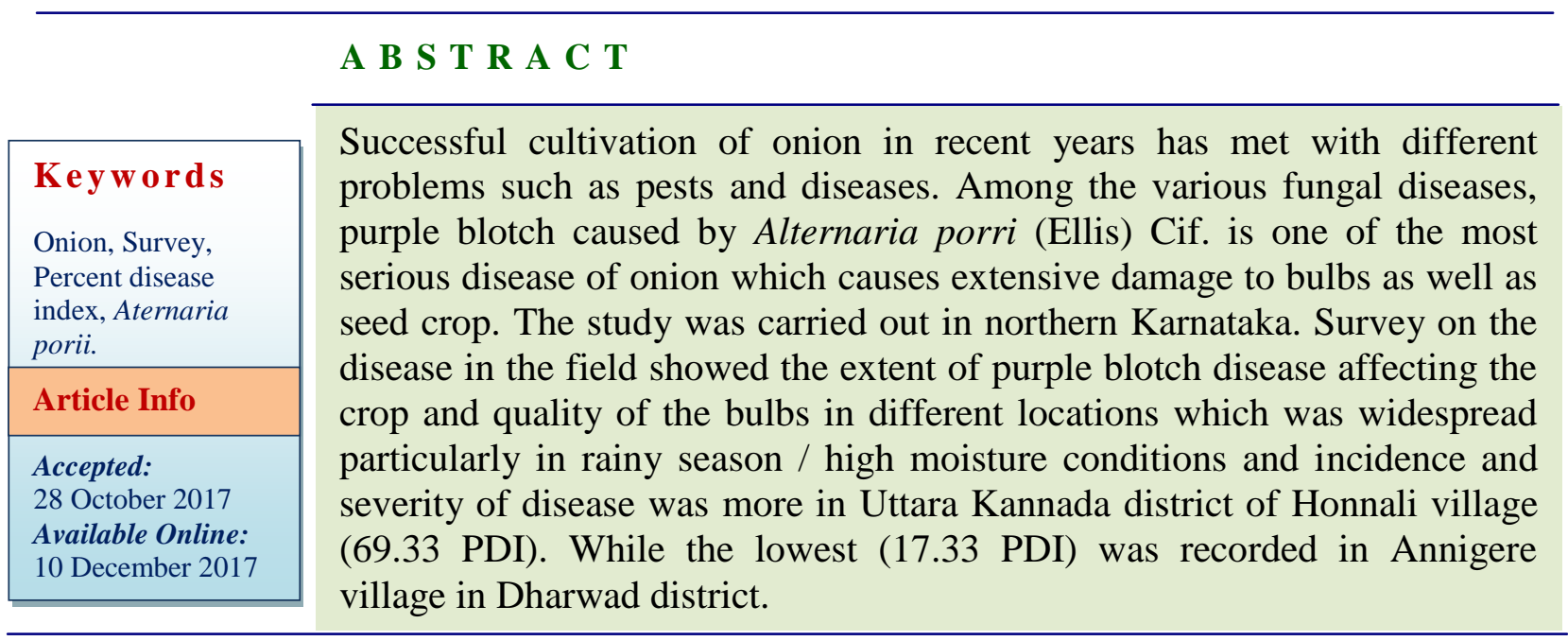

Introduction

Onion (Allium cepa L.) is one of the major bulb crops of India. Several factors have been identified for the low productivity of onion in India. The most important factors responsible are the diseases like purple blotch, downy mildew, Stemphylium blight, basal rot and storage rots and non-availability of varieties resistant to biotic and abiotic stresses. Among the foliar diseases, purple blotch is one of the most destructive diseases, commonly prevailing in almost all onion growing pockets of the world, which causes heavy loss in onions under field conditions. For the first time the purple blotch of onion caused by Alternaria cepulae was observed by Ponnappa (1970) in Karnataka. This was not recognized as a major foliar and inflorescence disease until recently, however now a day it is one of the important diseases. The name "Purple blotch" for this disease was proposed by Nolla (1927). He named the causal organism as Alternaria alli which was later amended as Alternaria porri.

A. porri destructs the leaf tissue which destroys the stimulus for bulb initiation and 
delays bulbing and maturation. Severe attack on flowering alliums can completely girdle flower stalks with necrotic tissue, causing their collapse and total loss of seed production capacity. Further, seed infection causes more severe economic loss in seed production. Sudarshanrao (1975) stated that survey and surveillance form the basis for any successful plant protection that depends on early detection of the disease followed by timely adoption of control measures. Hence, in the present investigation various aspects on Purple blotch was undertaken during the period 2011 to 2012 with reference to survey and surveillance of purple blotch disease in major onion growing areas of the northern Karnataka.

\section{Materials and Methods}

Roving survey was conducted during 2011-12 in major onion growing areas of Dharwad, Gadag, Haveri, Uttar Kannada and Belagavi districts of northern Karnataka in kharif and rabi seasons and observations of disease severity (PDI) was recorded on leaf different varieties and also observations recorded in two to three months old crop growth by following 0 to 5 scale given by Sharma (1986).

Percent disease index was calculated by using the following formula (Wheeler, 1969).

$$
\begin{gathered}
\text { Sum of disease ratings } \\
\begin{array}{c}
\text { Total number of observations } \times \\
\text { Highest disease grade }
\end{array}
\end{gathered}
$$

\section{Results and Discussion}

The disease appeared in an epiphytotic form in kharif 2011, damaging the major photosynthetic area of leaves on onion. It caused a heavy destruction in the yield of onion. It is possible that due to continuous growing of onion throughout the year, which is the main host of the pathogen, the disease might have appeared in epiphytotic form because of inoculum build-up. In recent years, this disease has become menace to onion growers in India.

The yield loss of onion in India due to this disease under favourable conditions varies from 25-50 per cent (Pandotra, 1964) more so in Karnataka.

A detailed roving survey was undertaken during kharif 2011 in parts of northern Karnataka to gather information on the symptomatology, severity, distribution and spread of Purple blotch of onion from different localities.

This information is highly useful to indentify the hot spots of this disease in Dharwad, Belagavi, Gadag, Haveri and Uttar Kannada districts where onion is extensively grown as commercial crop.

From the survey it is revealed that the severity of this disease varied from locality to locality (Table 1). The severity of disease was also dependent on inoculum load, environmental conditions prevailing in different localities.

Among the districts surveyed, the highest severity $(69.33 \%)$ of Purple blotch of onion was noticed in fields of Vonnali village in Uttar Kannada district, whereas least (17.33\%) per cent disease index of the disease were recorded at Annigeri village in Dharwad district.

The highest district average disease incidence was recorded in Uttar Kannda (61.21\%) followed by Belagavi (52.86\%), Haveri (43.32\%), Dharwad (41.48\%) and least incidence was noticed in Gadag (39.90\%) district indicating that this disease was not consistent in all localities. 
Table.1 Per cent disease index of purple blotch of onion in northern parts of Karnataka during 2011-2012

\begin{tabular}{|c|c|c|c|c|c|c|c|}
\hline District & Taluk & Village & Variety & $\begin{array}{c}\text { Stage of } \\
\text { crop } \\
\text { (DAS) }\end{array}$ & $\begin{array}{c}\text { Type of } \\
\text { soil }\end{array}$ & $\begin{array}{c}\text { Average no. of } \\
\text { Thrips /Plant }\end{array}$ & PDI \\
\hline \multirow{32}{*}{ Dharwad } & \multirow{6}{*}{ Dharwad } & Amminabhavi & Double Red & 80 & Black & 7 & 26.00 \\
\hline & & Harobelavadi & $\mathrm{N}-53$ & 85 & Black & 5 & 34.66 \\
\hline & & Shivalli & Nasik Red & 85 & Black & 6 & 54.60 \\
\hline & & Hebballi & Double Red & 75 & Black & 4 & 36.66 \\
\hline & & Kabbenuru & Double Red & 90 & Black & 3 & 57.40 \\
\hline & & Somapura & Local variety & 75 & Black & 6 & 34.13 \\
\hline & \multirow{5}{*}{ Hubli } & Bhadrapoora & Nasik Red & 85 & Black & 6 & 42.66 \\
\hline & & Hebsur & Nasik Red & 80 & Black & 7 & 40.00 \\
\hline & & Hubli & $\mathrm{N}-53$ & 75 & Black & 8 & 34.66 \\
\hline & & \begin{tabular}{|l|} 
Nalavadi \\
\end{tabular} & Bellary local & 70 & Black & 9 & 28.30 \\
\hline & & Shiraguppi & Nasik Red & 80 & Black & 6 & 26.33 \\
\hline & \multirow{6}{*}{ Kundagol } & Devanuru & Double Red & 85 & Black & 6 & 24.50 \\
\hline & & Elivara & Local variety & 80 & Black & 8 & 26.00 \\
\hline & & Hanchinala & Nasik Red & 90 & Black & 5 & 28.55 \\
\hline & & \begin{tabular}{|l|} 
Hosakatti \\
\end{tabular} & Local variety & 95 & Black & 6 & 38.30 \\
\hline & & Kambadhalli & Nasik Red & 90 & Black & 8 & 49.33 \\
\hline & & Kundagol & $\mathrm{N}-53$ & 70 & Black & 10 & 35.60 \\
\hline & \multirow{15}{*}{ Navalgund } & Alagawadi & Local variety & 95 & Black & 9 & 54.66 \\
\hline & & Amargol & Bellary Red & 80 & Black & 8 & 39.50 \\
\hline & & Aarekuratti & Double Red & 95 & Black & 10 & 45.60 \\
\hline & & Arratti & Double Red & 110 & Black & 7 & 66.60 \\
\hline & & \begin{tabular}{|l} 
Annigeri \\
\end{tabular} & Nasik Red & 80 & Black & 5 & 17.33 \\
\hline & & Belavatagi & Nasik Red & 85 & Black & 7 & 49.33 \\
\hline & & Halakusagol & Local variety & 95 & Black & 8 & 54.33 \\
\hline & & \begin{tabular}{|l|} 
Jagapur \\
\end{tabular} & Nasik Red & 95 & Black & 8 & 51.50 \\
\hline & & Kadadalli & Nasik Red & 105 & Black & 9 & 66.66 \\
\hline & & Karalawada & Bellary Red & 95 & Black & 9 & 49.33 \\
\hline & & \begin{tabular}{|l|} 
Karalgund \\
\end{tabular} & Nasik Red & 80 & Black & 11 & 56.00 \\
\hline & & \begin{tabular}{|l|} 
Padesur \\
\end{tabular} & Local variety & 80 & Black & 6 & 47.22 \\
\hline & & \begin{tabular}{|l|} 
Shanawad \\
\end{tabular} & Double Red & 90 & Black & 8 & 58.44 \\
\hline & & Sotakanala & Double Red & 110 & Black & 11 & 66.66 \\
\hline & & Thirlapura & Double Red & 80 & Black & 8 & 26.66 \\
\hline & Iean & & & & & 41.48 & \\
\hline \multirow{9}{*}{ Belagavi } & \multirow{5}{*}{ Savadatti } & Hireulligere & Nasik Red & 95 & Black & 6 & 47.22 \\
\hline & & Inamahongala & Nasik Red & 90 & Black & 6 & 51.40 \\
\hline & & Karikatte & Nasik Red & 95 & Black & 10 & 58.44 \\
\hline & & \begin{tabular}{|l|} 
Kallekabburu \\
\end{tabular} & \begin{tabular}{|l|} 
Local variety \\
\end{tabular} & 105 & Black & 16 & 64.54 \\
\hline & & Yadalli & Nasik Red & 110 & Black & 14 & 60.57 \\
\hline & \multirow{4}{*}{ Gokak } & Musaguppi & Local variety & 105 & Black & 13 & 63.33 \\
\hline & & \begin{tabular}{|l|} 
Nallanatti \\
\end{tabular} & Nasik Red & 95 & Black & 14 & 49.13 \\
\hline & & \begin{tabular}{|l|} 
Tigadi \\
\end{tabular} & Double Red & 90 & Black & 9 & 47.22 \\
\hline & & Vannur & Double Red & 90 & Black & 10 & 34.13 \\
\hline & Tean & & & & & 52.86 & \\
\hline \multirow{4}{*}{ Gadag } & \multirow{4}{*}{ Gadag } & Adavisomapura & Bellary local & 85 & Black & 8 & 45.00 \\
\hline & & Binkadakatti & Bellary local & 80 & Black & 6 & 34.64 \\
\hline & & \begin{tabular}{|l|} 
Hasundi \\
\end{tabular} & $\mathrm{N}-53$ & 90 & Black & 8 & 50.50 \\
\hline & & Hulkoti & Bellary local & 90 & Black & 9 & 46.00 \\
\hline
\end{tabular}




\begin{tabular}{|c|c|c|c|c|c|c|c|}
\hline & & Kandapura & Bellary local & 80 & Black & 10 & 39.60 \\
\hline & & Lakkundi & Local variety & 80 & Black & 8 & 38.56 \\
\hline & & Attikatti & Nasik Red & 85 & Black & 9 & 39.00 \\
\hline & Mundargi & Doni & Local variety & 85 & Black & 10 & 20.58 \\
\hline & & Doni thandya & Local variety & 80 & Black & 11 & 23.27 \\
\hline & & Kelakeri & Local variety & 80 & Black & 10 & 35.60 \\
\hline & Naragund & Konnura & Nasik Red & 86 & Black & 9 & 45.55 \\
\hline & & Naragund & $\mathrm{N}-53$ & 85 & Black & 12 & 40.52 \\
\hline & & Gojanuru & Bijapur local & 90 & Black & 10 & 48.77 \\
\hline & Shiratti & Lakshmeshwar & $\mathrm{N}-53$ & 95 & Black & 14 & 51.11 \\
\hline & ean & & & & & & \\
\hline & & Halageri & Nasik Red & 90 & Black & 6 & 40.12 \\
\hline & & Itagi & Local variety & 95 & Black & 7 & 53.33 \\
\hline & Donohonnur & \begin{tabular}{|l} 
Lingandahalli \\
\end{tabular} & Nasik Red & 105 & Black & 8 & 60.33 \\
\hline & Kaneoennu & Ranebennur & Nasik Red & 85 & Black & 7 & 40.80 \\
\hline Haveri & & Taredahalli & Local variety & 80 & Black & 7 & 47.22 \\
\hline & & Mannoora & Local variety & 95 & Black & 6 & 34.66 \\
\hline & & Savanur & Double Red & 90 & Black & 5 & 28.55 \\
\hline & Soyanur & Shirabedagi & Double Red & 95 & Black & 6 & 45.60 \\
\hline & Savanum & Guttala & Local variety & 90 & Black & 6 & 39.33 \\
\hline & ean & & & & & & \\
\hline & & Devanahalli & Local variety & 110 & Sandy & 13 & 58.40 \\
\hline & Ankola & Mirjan & Local variety & 110 & Sandy & 14 & 59.33 \\
\hline & & Shirali & Local variety & 115 & Sandy & 16 & 60.33 \\
\hline & Photlolo & Tenginagundi & Local variety & 98 & Sandy & 12 & 58.43 \\
\hline & Dnatkald & Nagabana & Local variety & 105 & Sandy & 15 & 60.33 \\
\hline Uttar Kannada & Honnavar & Mavinagundi & Local variety & 105 & Sandy & 16 & 60.66 \\
\hline & & Adekodi & Local variety & 110 & Sandy & 9 & 58.40 \\
\hline & & \begin{tabular}{|l} 
Alvekodi \\
\end{tabular} & Local variety & 110 & Sandy & 14 & 64.53 \\
\hline & Kumuta & Vonnali & Local variety & 105 & Sandy & 15 & 69.33 \\
\hline & & Handigona & Local variety & 108 & Sandy & 13 & 62.40 \\
\hline
\end{tabular}

Observations recorded in two to three months old crop growth by following 0 to 5 scale given by Sharma (1986)

\begin{tabular}{|c|c|}
\hline Grade & Percent area of infection \\
\hline 0 & No disease symptoms \\
\hline 1 & A few spots towards tip covering 10 per cent leaf area \\
\hline 2 & Several dark purplish brown patch covering upto 20 per cent leaf area \\
\hline 3 & Several patches with paler outer zone covering upto 40 per cent leaf area \\
\hline 4 & $\begin{array}{l}\text { Leaf streaks covering upto } 75 \text { per cent leaf area or breaking of the leaves } \\
\text { from centre }\end{array}$ \\
\hline 5 & Complete drying of the leaves or breaking of the leaves from centre \\
\hline
\end{tabular}

Onion was cultivated mostly in black soils, but in Uttar Kannada district onion is cultivated in sandy soils in irrigated condition. Disease was more with the age of crop. Thrips population was more in the Uttar Kannada district. Disease increased with increase in thrips population.
During survey various symptoms of the disease were noticed on leaves, flowering stalk, inflorescence and also on bulbs. At initial stages, leaves were with circular to oval watersoaked areas which later on, as the disease progressed, became oblong and a fresh zone of 
discoloured tissue was formed around the spots. Initially spots were white, but later turned pinkish or purple. The change in colour started from the centre and gradually progressed towards the periphery, where it changed into light purplish.

The transition of colour was marked by concentric rings clearly visible to the naked eye. The older leaves were more susceptible than younger leaves and were relatively more susceptible when they reach close to bulb maturity. Similar lesions formed on seed stalks of the inflorescence axes caused girdling and in most cases resulted in the destruction of the stalk. As a result of this, seeds either did not develop or if developed, they were shrivelled.

The leaf blight of onion was severe in Uttar Kannada district compared to Gadag district. This could be because of favourable environmental conditions and initial inoculum prevailed. This might have helped in the rapid development of the disease in kharif when favourable environmental conditions prevailed.

Working on survey of Alternaria leaf blight and other diseases of onion, Patil and Patil (1991) concluded that it is the most predominant and severe disease in the onion growing centers of Maharashtra. Srivastava et al., (1994) in their report on status of field diseases and insect pest of onion in India also indicated that purple blotch incidence was high in both rainy and post-rainy seasons when high humidity prevailed. Chethana (2000), who conducted survey in northern parts of Karnataka during kharif 1999 also revealed that incidence of purple blotch of onion was found in all districts of Northern Karnataka and noticed highest per cent disease incidence in Ronihal village
(Basavanabagewadi taluk) of Bijapur district and lowest in Wadullur village of Raichur taluk.

\section{References}

Chethana, B. S., 2000, Studies on Alternaria leaf blight of onion (Allium cepa L.). M. Sc. (Agri.) Thesis. Uni. Agric. Sci., Dharwad, Karnataka (India).

Nolla, J. A. B., 1927, A new Alternaria Disease of onions (Allium cepa). Phytopath, 17: 115-137.

Pandotra, V. R., 1964, Purple blotch disease of onion in Punjab. Its occurrence, pathogenicity and host range. Proc. Indian Acad. Sci., Section, 60: 331-340.

Patil, A. O. and Patil, B. C., 1992, Leaf blight of onion caused by Alternaria state of Pleospora infectoria. J. Maharashtra Agric. Uni. 17: 353.

Ponnappa K. M. 1970, Leaf blight of onion (Allium cepa) caused by Alternaria cepulae Ponnappa and Deshpande. NOVI, Comparative morphology and physiology. M. Sc (Agri.) Thesis University of Agricultural Sciences Bangalore.

Sharma, S. R., 1986, Effect of fungicidal sprays on purple blotch and bulb yield of onion. Indian Phytopath., 39 : 78-82.

Srivastava, P. K., Bharadwaj, B. S. and Gupta, P. P., 1994, Status of field diseases and selected pests of onion in India. Newsletter Nation. Hort. Res. Devel. Found., 14(2) : 11-14

Sudarshan Rao, A.N., 1975, Survey, surveillance and forecast in plant protection. Kissan World, 2: 43-44.

Wheeler, B. E. J., 1969, An introduction to plant diseases. John Wiley and Sons Ltd., London.

\section{How to cite this article:}

Ravichandran, S., B.C. Kamanna, K. Jayalakshmi, V.I. Benagi and Yadahalli, K.B. 2017. Severity of Purple Blotch of Onion Caused by Alternaria porii in Northern Karnataka. Int.J.Curr.Microbiol.App.Sci. 6(12): 3634-3638. doi: https://doi.org/10.20546/ijcmas.2017.612.419 